\title{
PHYSICAL AND CHEMICAL CHARACTERISTICS OF LETTUCE CULTIVARS GROWN UNDER THREE PRODUCTION SYSTEMS
}

\author{
CARACTERÍSTICAS FÍSICAS E QUÍMICAS DE CULTIVARES DE ALFACE \\ CULTIVADAS SOB TRESS SISTEMAS DE PRODUÇÃO
}

\author{
Luma Moreira MARTINS ${ }^{1}$; Ernani Clarete da SILVA $^{2}$; Lanamar de Almeida CARLOS ${ }^{3}$; \\ Leila de Castro Louback FERRAZ ${ }^{4}$; Gabriel Mascarenhas MACIEL ${ }^{5}$; Jessica Lorena CRUZ ${ }^{6}$ \\ 1. Engenheira Agrônoma, mestre em Ciências Agrárias, Departamento de Ciências Agrárias - CSL, Universidade Federal de São João \\ del - Rei - UFSJ, Sete Lagoas, MG, Brasil; 2. Docente Adjunto do Curso de Engenharia Agronômica e do Programa de Pós - graduação \\ em Ciências - CSL - UFSJ, Sete Lagoas, MG, Brasil. clarete@ufsj.edu.br; 3. Docente Adjunto do Curso de Engenharia de Alimentos e \\ do Programa de Pós - graduação - CSL - UFSJ, Sete Lagoas, MG, Brasil; 4. Docente Adjunto do Curso de Engenharia Agronômica - \\ CSL - UFSJ, Sete Lagoas, MG, Brasil; 5. Docente Adjunto do Curso de Agronomia da Universidade Federal de Uberlândia - UFU, \\ Monte Carmelo, MG, Brasil; 6. Graduando do curso de Engenharia de Alimentos - CSL - UFSJ, Sete Lagoas, MG, Brasil.
}

\begin{abstract}
Characteristics of food quality can affect the health of consumers and are influenced by several factors including the system of production. Lettuce has the highest sales volume of any leafy vegetable sold in Brazil and is considered a good source of vitamins, minerals and other compounds. This study aimed to determine the influence of the type of production system (conventional, organic and hydroponic) on the physical and chemical characteristics of two lettuce cultivars. Experiments were conducted simultaneously for each production system using a completely randomized design with three repetitions and two lettuce cultivars (Rubra and Crystal). Subsequently, a joint analysis of the three experiments was performed and averages compared by a Tukey test at 5\%. The following characteristics were evaluated: number of leaves, plant height, plant diameter, stem diameter, the fresh weight and dry weight of roots and plants, instrumental color, $\mathrm{pH}$, titratable acidity, total soluble solids, the ratio of soluble solids to titratable acidity and moisture content. It was concluded that the type of production system does affect attributes of lettuce quality with distinctions between cultivars. The most intense distinctions were found under the hydroponic system.
\end{abstract}

KEYWORDS: Lactuca sativa L. Production systems. Organic.

\section{INTRODUCTION}

Food quality is an aspect of nutrition and food safety that is related not only to food production and availability, but also to promoting the health of consumers (Silva et al., 2011). For food to be considered safe it must be free from any chemical compounds or products that may be harmful to humans (OLIVEIRA; HOFFMANN, 2015).

In last years, organic farming has grown in its potential to provide healthful foods and to reduce damage to the environment caused by conventional agricultural practices (HERENCIA, 2011). The motivation to buy organic products has increased due to concerns over health, the environment and most significantly, food safety (OZGUVEN, 2012).

Organic farming requires growers to eliminate the use of pesticides and highly concentrated and highly soluble fertilizers (BRASIL, 2015). Because organic systems promote conservation, they not only reduce damage to the environment but also yield high-quality products (SOUZA; RESENDE, 2006).Consumers are looking for foods such as fruits and vegetables with functional characteristics (MATTOS et al., 2009).
Non-organic production systems use high levels of pesticides and chemical fertilizers in order to control pests and pathogens and to improve the yield and appearance of harvested products. The viability of these systems has been widely questioned given the harm they cause to the environment and consumers (BARRIERE et al., 2015).

Therefore, it is necessary to study the effects of different production systems on the nutritional and productive aspects of vegetables, such as lettuce, since the different features of conventional, organic and hydroponic systems may influence the quality and the properties of these vegetables (MIYAZAWA et al., 2001).

Lettuce (Lactuca sativa L.) is important due to its impact on human health and nutrition, which arises from its significance as a source of vitamins and minerals, its worldwide popularity (MONTEIRO NETO et al., 2014), and because of its contribution to the creation of jobs and income (HEREDIA ZÁRETE et al., 2010).

Thus, this study aimed to evaluate the influence of different systems on the physical and chemical characteristics of two lettuce cultivars. 


\section{MATERIAL AND METHODS}

The experiment was carried out from May to June of 2015 at Quintas da Fazendinha (19³0' $\left.37,9 " \mathrm{~S}, 44^{\circ} 05^{\prime} 31,9{ }^{\prime} \mathrm{W}\right)$ located in the municipality of Matozinhos, within the central region of Minas Gerais, Brazil. The average altitude of this region is 808 meters above sea level. The soil is a Red-Yellow Latosol (Oxisol) with the following initial chemical properties: $\mathrm{pH}\left(\mathrm{CaCl}_{2}\right)=6.5, \mathrm{OM}=$ $47.3 \mathrm{~g} / \mathrm{dm}^{3}, \mathrm{P}(\mathrm{resin})=193.3 \mathrm{mg} \mathrm{dm}{ }^{3}, \mathrm{~K}=5.84$ mmolc $/ \mathrm{dm}^{3}, \mathrm{Ca}=162.2 \mathrm{mmolc} / \mathrm{dm}^{3}, \mathrm{Mg}=19.0$ $\mathrm{mmolc} / \mathrm{dm}^{3}$ and $\mathrm{V}=93.50 \%$.

Three experiments were conducted simultaneously in three distinct environments (production systems): organic, conventional and hydroponic. The experimental design was completely randomized for these three systems with two types of lettuce and three repetitions. The lettuce consisted of a purple colored experimental genotype from the loose-leaf lettuce group called Rubra and a curly green cultivar called Crystal. Afterwards, a joint analysis of the three experiments was performed.

The organic and conventional plots contained 16 plants grown in four rows and spaced $0.30 \mathrm{~m} \times 0.30 \mathrm{~m}$ for a total area of $1.44 \mathrm{~m}^{2}(1.20 \mathrm{~m} \mathrm{x}$ $1.20 \mathrm{~m}$ ). Only the 4 centermost plants from each plot were evaluated in the physical and chemical analysis. The conventional plots were fertilized according to the results of the soil analysis and the recommendations of Ribeiro et al. (1999).

The organic plots were fertilized with a topdressing of 25 kilograms of humus and 10 kilograms of compost made from poultry manure (poultry bedding), cow manure, sugarcane, chopped elephant grass and rock dust (Araxa rock phosphate and verdigris).

The hydroponic system consisted of 100 $\mathrm{mm}$ grow cups spaced $25 \mathrm{~cm}$ apart. The plots consisted of 12 plants arranged in three repetitions per cultivar.

The seedlings used in the conventional and organic systems were produced in disposable 128 cell Nutriplan trays that had been sanitized with chlorinated water and filled with a commercial substrate (Carolina - CSC). The seedlings for the hydroponic system were produced in phenolic foam cells measuring $2 \times 2 \times 2 \mathrm{~cm}$. The seedlings in the conventional and organic systems were transplanted with four true leaves, 30 days after sowing.

In the hydroponic system, seeds were sown in foam cells and maintained in nursery trays. After 7 days, the foam cells were transplanted into the hydroponic growth channels where they remained until the evaluation.

The nutrient solution for the hydroponic system was prepared according to Furlani et al. (1999). From 6am to 6pm, this solution was circulated in the system for 15 minute periods with 15 minute intervals. From $6 \mathrm{pm}$ to $6 \mathrm{am}$, the solution was circulated for 15 minute periods with 4 hour intervals. The irrigation system was triggered by a timer and powered by an electric pump. The nutrient solution had an electric conductivity of $1.8 \mathrm{mS} / \mathrm{cm}$ as recommended by Furlani et al. (1999).

All cultural and phytosanitary treatments were performed according to the recommendations of Souza; Resende (2006). Plants were irrigated by spraying and fertilized by a manually applied topdressing (conventional system).

The plants were stored in coolers immediately after harvesting and then transported in refrigerated containers to the Food Conservation Laboratory at the Federal University of São Joao del Rei (UFSJ) -Sete Lagoas Campus in Sete Lagoas, MG, Brazil where they were prepared and evaluated (chemical and physical characteristics).

Plant height was measured (in $\mathrm{mm}$ ) from the base of the stem (leaf insertion point) to the apex of the tallest leaf. Plant and stem diameters were determined, respectively, using a digital caliper (hardened stainless steel) and a ruler. Leaf number was determined by counting all leaves larger than five centimeters.

In order to determine the fresh and dry weights of the roots and shoots, the roots were first separated from the shoots and then both the roots and shoots were washed, weighed (precision scale), placed in paper bags and then dried for approximately seven days in a forced air oven at 65 ${ }^{\circ} \mathrm{C}$ until reaching a constant weight.

Colorimetric parameters were measured with a Konica Minolta CR410 colorimeter using three randomly selected leaves from the middle third of the plant. The colorimetric value for a leaf was obtained from the average of three readings taken at equidistant points on the leaf. These results were expressed using the CIELAB system (L, a *), where the $\mathrm{L}$ parameter refers to brightness $(0$ to $100)$ and the $a^{*}$ parameter refers to chromaticity (- a $*$ green to $+\mathrm{a} *$ red).

Total soluble solids (TSS) were determined by first macerating a representative leaf sample, filtering and then placing the consequent extract on the prism of a digital refractometer (Reichert R2 Mini). The results were expressed in ${ }^{\circ} \mathrm{Brix}$ (AOAC, 2012). 
Total acidity and $\mathrm{pH}$ and were determined by first macerating and filtering a 5-gram sample of lettuce leaves. Afterwards, $\mathrm{pH}$ was determined via potentiometry by immersing the electrode of a pHmetro digital Tekna T-1000 directly into the sample (AOAC, 2012). This same sample was then diluted with $50 \mathrm{~mL}$ of distilled water and titrated with standard $0.01 \mathrm{~N} \mathrm{NaOH}$ solution and a phenolphthalein indicator as recommended by AOAC (2012). The results were calculated using Equation (1) and expressed as mg citric acid / 100g of fresh sample.

$$
\text { Total Titrabable Acidity }=\left(\frac{\text { VxrxNxMW }}{10 \mathrm{xWxNH}}\right)(1)
$$

Where:

$\mathrm{V}=$ Volume of $\mathrm{NaOH}$ used in titration, $\mathrm{F}=$ Correction factor of the $\mathrm{NaOH}$ solution, $\mathrm{N}=$ Normality of the $\mathrm{NaOH}$ solution, $\mathrm{MW}=$ Molecular weight of citric acid, $\mathrm{W}=$ Sample weight $(\mathrm{g})$,

$\mathrm{NH}=$ Number of ionizable hydrogens.

Moisture levels of the lettuce leaves were determined from five gram samples weighed on an analytical balance. The leaves were dried by placing them in porcelain crucibles and drying in a sterilization drying oven at $105{ }^{\circ} \mathrm{C}$ until reaching a constant weight. Percent moisture was obtained from the difference between the initial and final sample weight (AOAC, 2012). The maturation rate was determined as the ratio of total soluble solids to total titratable acidity (TSS/TTA).

The data were submitted to analysis of variance and the means were compared by a Tukey test at 5\% using the SISVAR statistical program (Ferreira, 2008).

\section{RESULTS AND DISCUSSION}

Plant diameter is an important characteristic when selecting and selling vegetables at farmers' markets or grocery stores (SANTOS et al., 2009). Joint analysis showed a significant interaction between production systems and cultivars for this parameter. In the present study, the Rubra cultivar had a larger mean plant diameter than did the Crystal cultivar under the organic and conventional systems $(\mathrm{p}<0.5)$. However, this same difference was not observed in the hydroponic system (Table 1). The plant diameter of the Crystal cultivar did not differ significantly under the conventional, hydroponic and organic production systems. Moreover, the Rubra cultivar had a significantly smaller mean diameter under the hydroponic system than under the conventional and organic systems.

Table 1. Plant diameter $(\mathrm{cm})$ of the cultivars in function of different production systems

\begin{tabular}{lccc}
\hline Cultivars & \multicolumn{3}{c}{ Production Systems } \\
\cline { 2 - 4 } & Conventional & Hydroponic & Organic \\
\hline Rubra & $40.05^{\mathrm{aA}}$ & $35.72^{\mathrm{aB}}$ & $39.44^{\mathrm{aA}}$ \\
Crystal & $31.94^{\mathrm{bA}}$ & $35.05^{\mathrm{aA}}$ & $33.16^{\mathrm{bA}}$ \\
CV $(\%) 3.80$ & & &
\end{tabular}

General Average 35.89

Means followed by the same lower -case letters in columns and upper -case letters in rows do not fifer according to the Tukey test at $5 \%$.

Probably, in addition to the influence of the production systems of results, there is also an influence of the genotypes.

Significant interactions were not observed between cultivar and production system for Stem Diameter and Dry Root Weight. However, both cultivars and production systems responded significantly. The hydroponic environment favored larger stem diameters and greater dry root mass for the Crystal cultivar (Table 2). This greater root mass was probably due to the ease at which roots could expand in the hydroponic system without the obstacles encountered in soil.

Plant height differed significantly between the Crystal and Rubra cultivars regardless of production system (Table 3) and without any significant interactions. The lowest stem heights for both cultivars were found in the hydroponic system. These results are probably due to the different genotypes constituting the different cultivars.

Characteristics related to plant size, such as diameter and height, are of paramount importance in packing and shipping. Larger plants can be damaged during shipping, resulting in lower commercial quality (SALA; COSTA, 2012). The number of leaves did not differ significantly by production system or cultivar type (Table 3 ). 
Table 2 .Stem Diameter $(\mathrm{cm})$ and Dry Root Weight $(\mathrm{g})$ as a function of production system.

\begin{tabular}{lcc}
\hline Cultivars & \multicolumn{2}{c}{ Characteristics } \\
\cline { 2 - 3 } & Stem Diameter $(\mathrm{cm})$ & Dry Root Weight $(\mathrm{g})$ \\
\hline Crystal & $1.70^{\mathrm{a}}$ & $7.16^{\mathrm{a}}$ \\
Rubra & $1.20^{\mathrm{b}}$ & $3.3^{\mathrm{b}}$ \\
Production Systems & & \\
Hydroponic & $1.86^{\mathrm{a}}$ & $11.36^{\mathrm{a}}$ \\
Organic & $1.33^{\mathrm{b}}$ & $5.86^{\mathrm{b}}$ \\
Conventional & $1.16^{\mathrm{b}}$ & $4.27^{\mathrm{c}}$ \\
CV $(\%)$ & 12.79 & 9.70 \\
General Average & 1.75 & 5.23 \\
\hline
\end{tabular}

Means followed by the same letters do not differ according to the Tukey test at 5\%.

Table 3. Plant Height $(\mathrm{cm})$ and Number of Leaves as a function of production system

\begin{tabular}{lcc}
\hline Production Systems & \multicolumn{2}{c}{ Characteristics } \\
\cline { 2 - 3 } & Plant Height $(\mathrm{cm})$ & Number of Leaves \\
\hline Hydroponic & $18.02^{\mathrm{b}}$ & $19.33^{\mathrm{a}}$ \\
Conventional & $19.99^{\mathrm{a}}$ & $16.94^{\mathrm{a}}$ \\
Organic & $20.00^{\mathrm{a}}$ & $20.77^{\mathrm{a}}$ \\
CV $(\%)$ & 5.38 & 12.09 \\
General Average & 19.34 & 19.01 \\
\hline
\end{tabular}

Means followed by the same letters do not differ according to the Tukey test at $5 \%$.

According to Diamante et al. (2013), the number of leaves is important because it indicates how well the genetic material is adapted to the environment and indicates potential for commercial success. Greater numbers of leaves also indicate greater leaf area, increased fresh weight and consequently greater productivity (ARAÚJO et al., 2011). According to Santos et al. (2009), the number of leaves may be influenced by the environment such that the combination of environment and genetics produces physiological and morphological changes in vegetation. Nevertheless, the same was not observed in the present study indicating the non-influence of the environments in the different genotypes for the assessed characteristic.

There was significant interaction between the two cultivars and the production systems regarding plant fresh weight and plant dry weight. Moreover, the Crystal cultivar was superior to the Rubra cultivar regardless of production system and this result is likely due to the genotype (Table 4).

Table 4. Plant Fresh Weight (g) and Plant Dry Weight (g) as a function of the production system.

\begin{tabular}{|c|c|c|}
\hline \multirow[t]{2}{*}{ Cultivars } & \multicolumn{2}{|c|}{ Characteristics } \\
\hline & Plant Fresh Weight (g & Dry Plant Weight (g) \\
\hline Crystal & $418.16^{\mathrm{a}}$ & $15.73^{\mathrm{a}}$ \\
\hline Rubra & $185.47^{\mathrm{b}}$ & $8.63^{\mathrm{b}}$ \\
\hline CV (\%) & 10.84 & 14.80 \\
\hline General Average & 301.91 & 12.18 \\
\hline
\end{tabular}

Means followed by the same letters do not differ according to the Tukey test at $5 \%$.

According to Luz et al. (2010), productivity increases are related to plants with greater shoot diameter and weight. Significant differences were found in the dry weight of intercropped lettuce and arugula plants grown under organic and conventional production systems (OLIVEIRA et al.,2010). These findings are in agreement with those of the present study.
It occurred significant interaction between the fresh root weight of both cultivars and the three production systems. Dry root weight was highest under the hydroponic system, regardless of cultivar (Table 5). In the hydroponic system NFT the roots develop freely within the crop channels without the impediments naturally observed in the soil. . 
Table 5. Root Fresh Weight (g) as a function of cultivar and production system

\begin{tabular}{lccc}
\hline Cultivars & \multicolumn{3}{c}{ Production Systems } \\
\cline { 2 - 4 } & Conventional & Organic & Hydroponic \\
\hline Crystal & $13.80^{\mathrm{aB}}$ & $19.85^{\mathrm{aB}}$ & $57.07^{\mathrm{aA}}$ \\
Rubra & $6.90^{\mathrm{bB}}$ & $8.25^{\mathrm{bB}}$ & $36.86^{\mathrm{bA}}$ \\
CV $(\%) 12.61$ & & &
\end{tabular}

General Average 23.79

Means followed by the same lower-case letters in columns and upper-case letters in rows do not differ according to the Tukey test at $5 \%$.

The statistical difference found between the Rubra and Crystal cultivars regarding dry and fresh root weight is probably due to genetic variations between the cultivars. In general, genotype can interact with environmental factors such as fertility, temperature, humidity and light intensity, which may directly influence crop performance (BLIND; SILVA FILHO, 2015).

The importance of vegetable color as a commercial characteristic is due mainly to consumer preference for specific external colors (MOTA, et al., 2000).The Crystal cultivar showed greater luminosity than did the Rubra cultivar $(\mathrm{p}<0.5)$.
Nevertheless, there were no significant differences between the plants grown under the organic and conventional systems (Table 6). Probably this result is due to the plastic cover used in the hydroponic system and also to the genotype of the two cultivars.

The chromaticity parameter $a^{*}$ was statistically higher for the leaves of the Rubra cultivar, which tended towards red $\left(+\mathrm{a}^{*}\right)$, than for the Crystal cultivar which tended towards green ($\left.\mathrm{a}^{*}\right)$. The leaves of the plants grown under the hydroponic, organic and conventional systems did not differ significantly (Table 6).

Table 6.Colorimetric parameters L (luminosity) and $a^{*}\left(-a^{*}\right.$ green to $+a^{*}$ red) of the leaves of the Rubra and Crystal cultivars as a function of production system.

\begin{tabular}{lcc}
\hline \multicolumn{1}{c}{ Variables } & \multicolumn{2}{c}{ Characteristics } \\
\cline { 2 - 3 } & $\mathrm{L}$ & $\mathrm{a}^{*}$ \\
\hline Cultivars & $52.88^{\mathrm{a}}$ & $-20.79^{\mathrm{b}}$ \\
Crystal & $23.20^{\mathrm{b}}$ & $4.77^{\mathrm{a}}$ \\
Rubra & & \\
Production Systems & $39.42^{\mathrm{a}}$ & $12.52^{\mathrm{a}}$ \\
Hydroponic & $37.77^{\mathrm{b}}$ & $12.98^{\mathrm{a}}$ \\
Organic & $36.91^{\mathrm{b}}$ & $13.00^{\mathrm{a}}$ \\
Conventional & 1.58 & 9.70 \\
CV (\%) & 38.04 & 12.84 \\
General Average & & \\
\hline
\end{tabular}

Means followed by the same letters do not differ according to the Tukey test at 5\%.

Abiotic and biotic factors influence indicators of quality such as color, flavor and texture (SIMONNE et al.,2002). The color of fruits and vegetables is due to groups of natural pigments that include chlorophylls and anthocyanins. Chlorophylls are green and anthocyanins range from blue to red (KIDMOSE et al., 2002). These compounds are particularly important to lettuce quality (HODGES et al., 2000). According to Ryder (1999), the presence and distribution of anthocyanin and chlorophyll in lettuce can be influenced by genetic factors.

Acidity from organic acids determines the acid or tart flavor of fruits and vegetables
(AROUCHAET al., 2005). In general, vegetables have low acidity and are thus quite susceptible to bacterial spoilage (PASCHOALINO, 1997).

Significant interaction between cultivars and production systems was observed. However, the Rubra cultivar had significantly higher total titratable acidity than did the Crystal cultivar in the three production systems, without significant differences among the systems. This means that the type of production system did not affect acidity levels of the Rubra cultivar (Table 7). Conversely, the conventional system did significantly interfere with the total titratable acidity of the Crystal cultivar. 
Table 7.Total Titratable Acidity (mg citric acid/ $100 \mathrm{~g}$ of fresh sample) as a function of the cultivars and production systems.

\begin{tabular}{lccc}
\hline Cultivars & \multicolumn{3}{c}{ Production Systems } \\
\cline { 2 - 4 } & Conventional & Hydroponic & Organic \\
\hline Rubra & $57.04^{\mathrm{aA}}$ & $45.70^{\mathrm{aA}}$ & $50.79^{\mathrm{aA}}$ \\
Crystal & $26.05^{\mathrm{bB}}$ & $42.36^{\mathrm{bA}}$ & $39.15^{\mathrm{bAB}}$ \\
CV\%12.61 & & &
\end{tabular}

General Average 23.79

Means followed by the same lower-case letters in columns and upper-case letters in rows do not differ according to the Tukey test at $5 \%$.

According to Brecht et al. (2010), organic acid levels in foods may depend on variety and production conditions. Regarding $\mathrm{pH}$, there was a significant interaction between the cultivars and the production systems. The $\mathrm{pH}$ values of the Crystal cultivar remained statistically equal and thus did not undergo significant interference from the systems (Table 8). The Rubra cultivar, however, showed lower $\mathrm{pH}$ values in the hydroponic system and higher $\mathrm{pH}$ in the conventional system (Table 8).

Table 8. $\mathrm{pH}$ as a function of cultivars and production systems

\begin{tabular}{lccc}
\hline Cultivars & \multicolumn{3}{c}{ Production Systems } \\
\cline { 2 - 4 } & Conventional & Hydroponic & Organic \\
\hline Crystal & $6.31^{\mathrm{aA}}$ & $6.26^{\mathrm{aA}}$ & $6.18^{\mathrm{aA}}$ \\
Rubra & $6.50^{\mathrm{aA}}$ & $5.70^{\mathrm{bC}}$ & $6.01^{\mathrm{aB}}$ \\
CV $(\%) 1.80$ & & &
\end{tabular}

General Average 6.19

Means followed by the same lower-case letters in columns and upper-case letters in rows do not differ according to the Tukey test at $5 \%$.

According to Davies ; Hobson (1981), $\mathrm{pH}$ can be influenced by variety, food ripening stage, planting location, physical damage and season. Araújo et al. (2014) did not find significant differences in the $\mathrm{pH}$ and acidity of lettuce cultivars grown under organic and conventional systems. The nutritional value of food is determined by the levels of proteins, lipids, sugars and other total solids that are inversely proportional to moisture content (FAGUNDES et al.,2005).

In the present study, the moisture levels of the Rubra and Crystal cultivars did not differ significantly. The plants grown under the conventional system showed similar moisture percentages to those of plants grown under the organic and hydroponic systems with values ranging from 95.2 to $96.45 \%$.

According to Bourn; Prescott (2002), the moisture levels of plants grown under an organic system are lower than those grown under a conventional system. Favaro-Trindade et al. (2007) evaluated the influence of organic, conventional and hydroponic production systems on the quality of the Luisa cultivar of loose-leaf lettuce and found that plants grown in the organic system had similar moisture levels to those of the conventional system and higher than those of the hydroponic system.
These results do not corroborate those of the current study.

No significant interactions between cultivars and production systems and influence of the systems on the cultivars were observed for total soluble solids (TSS). However, the ${ }^{\circ}$ BRIX value for the Rubra cultivar (3.34) was significantly higher than that of the Crystal cultivar (2.79). This difference is probably due to inherent differences in these genotypes.

According to Andriolo et al. (2005), the level of total soluble solids is strongly influenced by environmental factors such as temperature, fertilization, light and plant density. Silva et al.(2011) evaluated the effect of organic, conventional and hydroponic systems on total soluble solids in the Vera cultivar and did not find any differences between the organic and conventional systems, which produced TSS values greater than that produced under the hydroponic system.

The maturation ratio between total soluble solids and total titratable acidity (TSS/TTA) is considered to be the best way to evaluate flavor (CHITARRA; CHITARRA, 2005). A higher ratio shows a better balance between sweetness and acidity and a more pleasing flavor (AMORIM et al., 2010). This ratio differed significantly between the 
Crystal cultivar (26.59) and the Rubra cultivar (22.17). Nevertheless, both ratios were above the threshold of 10.0 for high quality vegetables (MENCARELLI; SALTVEIT, 1988).

Both total soluble solids and acidity can be influenced by environmental and genetic factors, resulting in variations in the ratio. Environmental variations can actively cause changes in crop morphology and productivity (BLIND; SILVA FILHO, 2015), which can restrict vegetable development (SANTOS et al., 2010).

\section{CONCLUSIONS}

In general, the organic and conventional production systems did not influence the physical and chemical characteristics of the plants evaluated in the current study.

Genotype may have produced the differences found in the physical and chemical characteristics that did differ between the organic and conventional systems.

\section{ACKNOWLEDGEMENTS}

The authors thank FAPEMIG and UFSJ for their financial support.

RESUMO: Características de qualidade de alimentos são atributos que estão relacionados com a saúde dos consumidores os quais podem ser influenciados por diversos fatores, dentre eles, os sistemas de produção. A alface é a hortaliça folhosa mais comercializada no Brasil e considerada fonte de vitaminas, sais minerais e outros compostos. O objetivo do presente trabalho foi estudar a influência de sistemas de produção (orgânico, convencional e hidropônico) nas características físicas e químicas de duas cultivares de alface. Foram conduzidos simultaneamente três experimentos, um em cada sistema de produção em delineamento experimental inteiramente ao acaso com três repetições e duas cultivares de alface (Rubra e Cristal). Posteriormente, uma análise conjunta dos três experimentos foi realizada e as médias submetidas ao teste de Tukey com 5\% de probabilidade. As seguintes características foram avaliadas: número de folhas, altura de plantas, diâmetro de planta e de caule, peso fresco e massa seca de raízes e plantas, cor instrumental, pH, acidez titulável, sólidos solúveis totais, ratio e umidade. Concluiu-se que há influência dos sistemas de produção em atributos de qualidade da alface de maneira distinta entre as cultivares com maior intensidade do sistema de produção hidropônico.

PALAVRAS-CHAVE: Lactuca sativa L. Sistemas de produção. Orgânico.

\section{REFERENCES}

AMORIM, G. M; SANTOS, T. C. dos; PACHECO, C. S. V; TAVARES, I. M. C; FRANCO, M. Avaliação microbiológica, físico-química e sensorial de polpas de frutas comercializadas em Itapetinga-BA. Enciclopédia Biosfera, v. 6, p. 1-8, 2010.

ANDRIOLO, J. L; LUZ G. L; BORTOLOTTO, O. C; GODOI, R. S. Produtividade e qualidade de frutos de meloeiro cultivado em substrato com três doses de solução nutritiva. Ciência Rural, v. 35, p. 781-787, 2005.<http://www.scielo.br/pdf/cr/v35n4/a05v35n4.pdf $>$. 19 Jan. 2016.

AOAC. Official Methods of Analysis of the Association of Official Analytical Chemistry.Gaitherburg: AOAC,2012. 3000p.

ARAÚJO, D. F. S; SILVA, A. M. R. B.; LIMA, L. L. A; VASCONCELOS, M. A. S; ANDRADE, S. A. C; SARUBBO, L. A. The concentration of minerals andphysico chemical contaminants in conventional and organic vegetables .Food Control, v. 44, p. 242-248, 2014.< doi:10.1016/j.foodcont.2014.04.005>.

ARAÚJO, W. F; SOUSA, K. T. S.; VIANA, T. V. A; AZEVEDO, B. M.; BARROS, M. M; MARCOLLINO, E. Resposta da alface a adubação nitrogenada. Revista Agro@mbiente Online, v. 5, n. 1. p. 12-17, 2011. $<$ http://revista.ufrr.br/index.php/agroambiente/article/viewFile/440/427>. 19 Jan. 2016. 
AROUCHA, E. M. M; SOUZA, C. L. M; AROUCHA, M. C. M; VIANNI, R. Características físicas e químicas da agua de coco anão verde e anão vermelho em diferentes estádios de maturação. Caatinga, v. 18, n. 2, p. 8287, 2005.<https://www.researchgate.net/publication>. 23 Dez. 2015.

BARRIERE, V; LECOMPTE, F; FRANÇOISE, L. Efficacy of pest and pathogen control, yield and quality of winter lettuce crops managed with reduced pesticide applications. European Journal of Agronomy, v. 71, p. 34-43, 2015.< doi:10.1016/j.eja.2015.07.003>.

BLIND, A.D; SILVA FILHO, D.F. Desempenho produtivo de cultivares de alface americana na estação seca da Amazônia central. Bioscience Journal, v.31, p,404-414,

2015.<http://www.seer.ufu.br/index.php/biosciencejournal/article/view/22352/16115>. 20 Jan. 2016.

BOURN, D; PRESCOTT, J. A comparison of the nutritional value, sensory qualities, and food safety of organically and conventionally produced food. Critical Reviews in Food Science and Nutrition, v. 42, n. 1, p. $1-34,2002 .<10.1080 / 10408690290825439>$

Brasil, Ministério da Agricultura e Abastecimento. Lei no 10.831, de 23 de dezembro de 2003. Dispõe sobre a agricultura orgânica. Brasília, DF, 2007.<www.agricultura.gov.br $\geq 15$ Dez. 2015.

BRECHT, J. K; RITENOUR, M. A; HAARDE, N. F; CHISM, G. W. Fisiologia pós-colheita de tecidos vegetais comestíveis. In: Damodaran, S; Parkin, K. L; Fennema, O. R. Química de Alimentos de Fennema. Porto Alegre: Artmed. 2010. 4ed, p. 760-815.

CHITARRA, M. I. F; CHITARRA, A. B. Pós-colheita de frutos e hortaliças: fisiologia e manuseio. Lavras:Editora UFLA, 2005. 785p.

DAVIES, J. N; HOBSON, G. E. The constituents of tomato fruit: the influence of environment, nutrition and genotype. Critical Review in Food Science Nutrition, v. 15, n. 3, p. 205-280,

1981.<http://www.ncbi.nlm.nih.gov/pubmed/7030623>. 20 Dez. 2015.

DIAMANTE, M. S; SEABRA JUNIOR, S; INAGAKI, A. M; SILVA, M. B; DALLACORT, R. Produção e resistência ao pendoamento de alfaces tipo lisa cultivadas sob diferentes ambientes. Revista Ciências Agronômica, v. 4, n. 1, p. 133-140, 2013.<http://www.scielo.br/pdf/rca/v44n1/a17v44n1.pdf>. 19 Abr. 2016.

FAGUNDES, A. F; ONUKI, N. S; RAUPP, D. S; GARDINGO, J. R; BORSATO, A. V. Influência do grau de umidade na textura do tomate seco refrigerado ou envasado em óleo. Ciências Exatas e da Terra, v. 11, n. 1, p. 35-42, 2005.<http://www.revistas2.uepg.br/index.php/exatas/article/viewFile/843/727>. 02 Jun. 2016.

FAVARO-TRINDADE, C. S; MARTELLO, L. S; MARCATTI, B; MORETTI, T. S; PETRUS, R. R; ALMEIDA, E.; FERRAZ, J. B. S. Efeito dos Sistemas de Cultivo Orgânico, Hidropônico e Convencional na Qualidade de Alface Lisa. Brazilian Journal FoodTechnology, v. 10, n. 2, p. 111-115, 2007.<http://bj.ital.sp.gov.br/artigos/bjft/2007/p06280.pdf>19 Abr. 2016.

Ferreira, D. F. SISVAR: um programa para análises e ensino de estatística. Revista Cientifica Symposium,v.6, n. 2, p. 36-41, 2008.<http://www.dex.ufla.br/ danielff/meusarquivospdf/art63.pdf> 19 Abr. 2016.

FURLANI, P. R; SILVEIRA, L. C. P; BOLONHEZI, D; FAQUINI, V. Cultivo hidropônico de plantas. Boletim Técnico 180, Campinas: Instituto Agronômico, 1999. 52p.

HODGES, D. M; FORNEY, C. F;WISMER, W. Processing line effects on storage attributes of fresh-cut spinach leaves. HortScience, v. 35, n. 7, p. 108-1311, 2000. $<$ http://hortsci.ashspublications.org/content/35/7/1308.full.pdf $>$. 20 Jan. 2016. 
HERENCIA, J. F; GARCÍA-GALAVIS, P. A; DORADO, J. A. R; MAQUEDA, C. Comparison of nutritional quality of the crops grown in an organic and conventional fertilized soil. Scientia Horticulturae, v. 129, n. 4, p. 882-888, 2011.<doi:10.1016/j.scienta.2011.04.008>

HEREDIA ZÁRETE, N. A; VIEIRA, M. C; HELMICH, M; HEID, D. M; MENEGATI, C. T. Produção agroeconômica de três variedades de alface: cultivo com e sem amontoa. Revista Ciência Agronômica, v. 41, n. 4, p. 646-653, 2010.< http://dx.doi.org/10.1590/S1806-66902010000400019>.

KIDMOSE, U; EDELENBOS, R; NORBAEK P. C. Colour stability in vegetables.In: Macdougall, D.B. Colour in food: Improving quality, Cambridge, 2002, p. 179-232.

LUZ, J. M. Q.; OLIVEIRA, G; QUEIROZ A. A; CARREON, R. Aplicação foliar de fertilizantes organominerais em cultura de alface. Horticultura Brasileira, v. 28, n. 3, p. 373-377,

2010.<http://www.scielo.br/pdf/hb/v28n3/v28n3a23.pdf>. 20 Jan. 2016.

MATTOS, L. M; MORETTI, C. L; MOURA, M. A. DE; MALDONADE, I. R; SILVA, E. Y. Y. Produção segura e rastreabilidade de hortaliças. Horticultura Brasileira, v. 27, n. 4, p. 408-413, 2009.< http://dx.doi.org/10.1590/S0102-05362009000400002>.

MENCARELLI, F; SALTVEIT. M. E. Ripening of mature-green tomato fruit slices. Journal of American Society for Horticultural Science, v. 113, n. 5, p. 742-745, 1988.<http://agris.fao.org/agrissearch/search.do?recordID=US8842650>.19 Abr. 2016.

MIYAZAWA, M; KHATOUNIAN, C.A; ODENATH-PENHA, L.A. Teor de nitrato nas folhas de alface produzida em cultivo convencional, orgânico e hidropônico. Agroecologia Hoje, v.2, n.7, p.23,

2001.<http://www.iapar.br/arquivos/File/zip_pdf/teor_de_nitrato.pdf>. 19 Abr.2016.

MOTA, W. F; FINGER, F. L; CASALI, V. W. D. Olericultura: Melhoramento Genético do Quiabeiro. Viçosa: Editora UFV, 2000. 144p

MONTEIRO NETO, J. L. L; SILVA, A. C. D.; SAKAZAKI, R. T; TRASSATO, L. B; ARAÚJO, W. F. Tipos de coberturas de solo no cultivo de alface (Lactuca sativa $\mathrm{L}$.) sob as condições climáticas de Boa Vista. Boletim do Museu Integrado de Roraima, v. 8, n. 2, p. 47-52, 2014.<http://uerr.edu.br/bolmirr/wpcontent/uploads/2014/12/BOLMIRR-v82-Monteiro-Neto-et-al.pdf>

OLIVEIRA, F. C. R; HOFFMANN, R. Consumo de alimentos orgânicos e de produtos light ou diet no Brasil: fatores condicionantes e elasticidades-renda. Segurança Alimentar e Nutricional, v. 22, n. 1, p. 541-557, 2015.<http://periodicos.sbu.unicamp.br/>. 02 Jun. 2016.

OLIVEIRA, E. Q. SOUZA, R. J; CRUZ, M. C. M; MARQUES, V. B; FRANÇA, A. C. Produtividade de alface e rúcula, em sistema consorciado, sob adubação orgânica e mineral. Horticultura Brasileira, v. 28, n. 1, p. 3640, 2010.<http://www.scielo.br/pdf/hb/v28n1/a07v28n1>. 02 Jun. 2016.

OZGUVEN, N. Organic foods motivations factors for consumers. Social and Behavioral Sciences, v. 62, p. 661-665, 2012.< $\underline{\text { doi:10.1016/j.sbspro.2012.09.110> }}$

PASCHOALINO, J. E. Hortaliças acidificadas em conserva: riscos e cuidados. Informativo Fruthotec, p. 1-3, 1997.

RIBEIRO, A. C; GUIMARÃES, P. T. G; ALAVAREZ, V. V. H. Recomendações para o uso de corretivos e fertilizantes em Minas Gerais.Viçosa:Editora UFV, 1999, 358p.

RYDER, E. J. Lettuce, endive and chicory.New York: Cabi Publishing Series, 1999. 208p. 
SALA, F.C; COSTA, C.P. Retrospectiva e tendência da alfacicultura brasileira. Horticultura Brasileira, v.30, n.2, p.187-194, 2012<http://dx.doi.org/10.1590/S0102-05362012000200002>

SANTOS, L. L; SEABRA JUNIOR, S; NUNES, M. C. M. Luminosidade, temperatura do ar e do solo em ambientes de cultivo protegido. Revista de Ciências Agro-Ambientais, v. 8, n. 1, p. 83- 93,

2010.<http://www.unemat.br/revistas/rcaa/docs/vol8/8_artigo_v8.pdf>. 02 Jun.2016.

SANTOS, C. L; SEABRA JUNIOR, S; LALLA, J. G.; THEODORO, V. C. A; NESPOLI, A. Desempenho de cultivares tipo crespa sob altas temperaturas Cáceres- MT. Agrarian, v. 2, n. 3, p. 87-98,

2009.<http://www.periodicos.ufgd.edu.br/index.php/agrarian/article/view/421/312>. 02 Jun. 2016.

SILVA, E. M. N. C. P. FERREIRA, R. L. F; ARAÚJO NETO, S. E; TAVELLA, L. B; SOLINO, A. J. S. Qualidade de alface crespa cultivada em sistema orgânico, convencional e hidropônico. Horticultura Brasileira, v. 29, n. 2, p. 242-245, 2011.< http://dx.doi.org/10.1590/S0102-05362011000200019>

SIMONNE, A; SIMONNE, E; EITENMILLER, R; COKER, C.H. Bitterness and composition of lettuce varieties grown in the southeastern United States.HortTechnology, v.12, n.4, p.721-726, 2002.<http://horttech.ashspublications.org/>.02 Jun. 2016.

SOUZA, J. L; RESENDE, P. L. Manual de horticultura orgânica. Viçosa: Editora UFV, 2006. 843p. 